Research Article

\title{
Evaluation on Antidiabetic Properties of Medicinal Plants from Myanmar
}

\author{
Dongdong Zhang $\mathbb{D}^{1,2,3}$ Karuppusamy Arunachalam ${ }^{10},{ }^{1}$ Yuehu Wang, ${ }^{1}$ Yu Zhang $\mathbb{D},{ }^{1}$ \\ Jun Yang, ${ }^{1}$ Pyae Phyo Hein, ${ }^{1,2}$ Aye Mya Mon $\mathbb{D}^{1,}{ }^{1,2}$ Jianwen Li $\mathbb{D}{ }^{1},{ }^{1}$ Angkhana Inta $\mathbb{D}^{3},{ }^{3}$ \\ and Xuefei Yang $\mathbb{D}^{1,2}$ \\ ${ }^{1}$ Key Laboratory of Economic Plants and Biotechnology and the Yunnan Key Laboratory for Wild Plant Resources, \\ Kunming Institute of Botany, Chinese Academy of Sciences, Kunming 650201, China \\ ${ }^{2}$ Southeast Asia Biodiversity Research Institute, Chinese Academy of Sciences, Yezin, Nay Pyi Taw 05282, Myanmar \\ ${ }^{3}$ Department of Biology, Faculty of Science, Chiang Mai University, 239 Huay Kaew Road, Chiang Mai 50200, Thailand
}

Correspondence should be addressed to Angkhana Inta; aungkanainta@hotmail.com and Xuefei Yang; xuefei@mail.kib.ac.cn

Received 8 June 2021; Revised 3 August 2021; Accepted 12 August 2021; Published 26 August 2021

Academic Editor: Wen Jun Li

Copyright (c) 2021 Dongdong Zhang et al. This is an open access article distributed under the Creative Commons Attribution License, which permits unrestricted use, distribution, and reproduction in any medium, provided the original work is properly cited.

\begin{abstract}
Objectives. To explore the effective and safe medicines for treating diabetes. Methods. Hydroalcoholic extracts of 130 medicinal plants belonging to 66 families were evaluated using porcine pancreatic lipase (PPL) inhibition and glucose uptake methods together with a literature review. Results. The extracts of 22 species showed the PPL inhibition activity; 18 extracts of 15 species stimulated glucose uptake in 3T3-L1 adipocytes. Among them, Mansonia gagei J.R. Drumm., Mesua ferrea L., and Centella asiatica (L.) Urb. exhibited both activities. The extracts of Caladium lindenii (André) Madison rhizomes and Azadirachta indica A. Juss. leaves presented the utmost lipase inhibitory activity with $\mathrm{IC}_{50}$ of $6.86 \pm 0.25$ and $11.46 \pm 0.06 \mu \mathrm{g} / \mathrm{mL}$, respectively. The extracts of Coptis teeta Wall. rhizomes and Croton tiglium L. seeds stimulated the maximum glucose uptake. Ten species are reported to have antidiabetic activity for the first time. Flavonoids and triterpenoids are the dominant antidiabetic compounds in selected medicinal plants from Myanmar. Conclusions. P. zeylanica, L. cubeba, H. crenulate, M. gagei, C. teeta, and M. ferrea are worthy to advance further study according to their strong antidiabetic activities and limited research on effects in in vivo animal studies, unclear chemical constitutes, and safety.
\end{abstract}

\section{Introduction}

Diabetes mellitus (DM) is a chronic metabolic disease and characterized by hyperglycemia that result from defects in insulin secretion, insulin action, or both [1]. Diabetes includes three main types, type I, type II, and gestational diabetes. Type II diabetes mellitus (T2DM) is the most common and accounts for over $90 \%$ of the total cases $[2,3]$. T2DM has high morbidity and mortality worldwide and brings a large economic burden. Cardiovascular complications are a major cause of morbidity and mortality among people with diabetes [2]. The International Diabetes Federation reported that there were 463 million adults with diabetes in 2019, which have more than tripled over the past
20 years, and diabetes-related healthcare costs (USD 760 billion) are now estimated to account for $10 \%$ of the total healthcare budget (https://www.diabetesatlas.org/).

Most patients with T2DM are overweight or obese. Pancreatic lipase is an important enzyme for digestion and absorption of dietary lipids, and lipase inhibition is the most widely studied for the discovery of potential antiobesity agents [4]. Monogenic and common forms of obesity initially cause insulin resistance [5]. Insulin resistance stimulates glucose production in the liver and attenuates glucose uptake in muscle and adipose tissue which is one of the important factors resulting in T2DM [2]. As the behavior of 3T3-L1 adipocytes is similar to primary adipocytes and mostly available muscle cell lines are not insulin sensitive in 
glucose transport, 3T3-L1 adipocytes have become the most preferred cell line to study insulin-stimulated glucose uptake and an excellent cell model to study insulin action and signaling [6].

Currently, oral antidiabetic medications are mainly classified as biguanides, sulfonylureas, meglitinides, thiazolidinediones, dipeptidyl peptidase 4 (DPP-4) inhibitors, sodium-glucose cotransporter inhibitors, and $\alpha$-glucosidase inhibitors [1]. These agents have adverse effects such as leading to hypoglycemia, cardiovascular, and metabolic alterations. People prefer medicinal plants for DM therapy due to low cost, minimal side effects, and inexpensive availability $[1,7]$. In many parts of the world, traditional knowledge and biodiversity play an import role in health care, and many widely used plant-based medicines are derived from traditional knowledge [8]. However, only parts of medicinal plants have received scientific evaluation for their efficacy [7]. Thus, it is a challenge and an opportunity to search medicinal plants to treat diabetes and its complications.

Myanmar, a tropical country, possesses a rich resource of medicinal plants, which is widely practiced by the majority of the population [9]. However, there are limited pharmacological studies on traditional medicines. Aumeeruddy et al. reviewed the ethnomedicinal plants for the management of diabetes worldwide but lack of information in Myanmar [10]. To explore the pharmacological application of antidiabetic properties of traditional plants in Myanmar and search for new antidiabetic agents, we investigated three main regions of the medicinal plants source and reported their current research status on antidiabetes. These species were screened for the antidiabetic activities by porcine pancreatic lipase (PPL) inhibition and glucose uptake in 3T3-L1 adipocyte assays of selected medicinal plants in Myanmar.

\section{Materials and Methods}

2.1. Investigation and Collection of Medicinal Plant Materials. This study was carried out in the markets and villages of three regions including Mandalay, Sagaing, and Shan State in 2015-2017. These places possess affluent medicinal plants according to our survey in Myanmar. Mandalay has the biggest market of medicinal plants, which is Zay Cho market. Shan is the biggest state and the most famous for its traditional medicines in Myanmar [11]. The local name and usage of medicinal plants were recorded in the field survey. Meanwhile, the voucher specimens and materials were collected for identification and further research, respectively. Among them, 93 samples of medicinal plants from Mandalay were screened for antibacterial and anti-T3SS activities in our previous research [12]. The plants were identified by Ms. Jun Yang and Mr. Yu Zhang from the Kunming Institute of Botany based on specimens. The plant names and families were confirmed and conducted at the Plant List (http://www. theplantlist.org).

2.2. A Review of Medicinal Plants in Antidiabetic Research. To make clear the status quo on antidiabetes of these medicinal plants, we performed a thorough literature review by using electronic databases (Web of Science, PubMed, Google Scholar, and SciFinder). Specific keywords include "scientific name of species" and "diabetes" until 2021. The used parts of the species were searched about their antidiabetes including traditional use, in vitro assay, in vivo animal studies, clinical trials, and antidiabetic constitutes. Other parts were continued to search if the collected parts did not report any antidiabetic properties, and other species of the same genus were continued to collect information if the species did not report any antidiabetes. We used rigorous inclusion and exclusion criteria to select antidiabetic compounds with IC $_{50} \leq 50 \mu \mathrm{M}$, or dose $\leq 50 \mu \mathrm{M}$ in vitro, or dose $\leq 50 \mathrm{mg} / \mathrm{kg}$ in vivo, excluding compounds with name or structure inconsistent with the source. Here, we refer to the antidiabetic activity of compounds with $\mathrm{IC}_{50} \leq 10 \mu \mathrm{M}$, dose $\leq 10 \mathrm{mg} / \mathrm{kg}$ in vivo, or dose $\leq 10 \mu \mathrm{M}$ in vitro as high and from 11 to 50 as moderate.

2.3. Preparation of Plant Extracts. The dried different parts of the plants were powdered in a grinder and then extracted with $70 \%$ ethanol at $60^{\circ} \mathrm{C}$ once for 30 minutes. After filtration, the solvent was removed under reduced pressure at $60^{\circ} \mathrm{C}$ in a rotary evaporator. The extracts were stored at $4^{\circ} \mathrm{C}$ before analysis.

2.4. Porcine Pancreatic Lipase (PPL) Inhibition Assay. Lipase inhibition activity was conducted as described in literature with some modifications [13]. Briefly, $p$-NPB was used as a substrate. The reactions were carried out in a 96-well microtiter plate where $5 \mu \mathrm{L}$ of lipase solution (40 $\mathrm{U} / \mathrm{mL}$ ) in Tris- $\mathrm{HCl}$ buffer (100 mM Tris- $\mathrm{HCl}, 5 \mathrm{mM} \mathrm{CaCl}$; $\mathrm{pH}$ 7.0) was used as enzyme buffer. Then, $1 \mu \mathrm{L}$ of each extract dissolved in dimethyl sulfoxide (DMSO) $(20 \mathrm{mg} /$ $\mathrm{mL}$ ) and $184 \mu \mathrm{L}$ of the same Tris- $\mathrm{HCl}$ buffer were added and mixed with the enzyme buffer. After incubation at $37^{\circ} \mathrm{C}$ for $15 \mathrm{~min}, 10 \mu \mathrm{L}$ of the substrate solution $(10 \mathrm{mM}$ $p$-NPB in DMSO) was added. Then, enzymatic reactions were performed for $15 \mathrm{~min}$ at $37^{\circ} \mathrm{C}$. Lipase activity was determined by measuring the hydrolysis of $p$-NPB to $p$-nitrophenol at $400 \mathrm{~nm}$ using a microplate reader, $630 \mathrm{~nm}$ as a reference. Orlistat was used as a positive control. The inhibitory activity (I) was calculated according to the following formula:

$$
I(\%)=\left(1-\frac{A}{B}\right) \times 100 \%
$$

$A$ is the optical density (OD) value of the sample. $B$ is the OD value of negative control.

The half-maximal inhibitory concentration $\left(\mathrm{IC}_{50}\right)$ was calculated by Reed and Muench's method.

2.5. Glucose Uptake in 3T3-L1 Adipocytes Assay. The differentiation of 3T3-L1 adipocytes and glucose uptake assay were carried out using a mild modified method described [14]. The differentiated 3T3-L1 adipocytes were seeded in 96-well plates and preincubated with the same way in 
TABLE 1: Ethnobotanical information and the PPL inhibition activity of seven species.

\begin{tabular}{|c|c|c|c|c|c|c|c|}
\hline Scientific name & Family & $\begin{array}{l}\text { Myanmar } \\
\text { name }\end{array}$ & $\begin{array}{c}\text { Common } \\
\text { name }\end{array}$ & Part $^{\mathrm{a}}$ & $\begin{array}{c}\text { Yield }^{\mathrm{b}} \\
(\%)\end{array}$ & Traditional use in Myanmar & $\begin{array}{c}\mathrm{IC}_{50} \\
(\mu \mathrm{g} / \mathrm{mL})\end{array}$ \\
\hline $\begin{array}{l}\text { Azadirachta } \\
\text { indica A. Juss. }\end{array}$ & Meliaceae & Tama & Neem & $\mathrm{L}$ & 12 & $\begin{array}{l}\text { The decoction of leaves is orally taken } \\
\text { for diabetes and antiseptic purpose. } \\
\text { Leaves are externally used for skin } \\
\text { diseases [9] }\end{array}$ & $11.46 \pm 0.06$ \\
\hline $\begin{array}{l}\text { Caladium } \\
\text { lindenii (André) } \\
\text { madison }\end{array}$ & Araceae & Gamon-gya & Indian kale & $\mathrm{Rh}$ & 21 & Undocumented & $6.86 \pm 0.25$ \\
\hline $\begin{array}{l}\text { Plumbago } \\
\text { zeylanica L. }\end{array}$ & Plumbaginaceae & $\begin{array}{c}\text { Kant- } \\
\text { gyoke-phyu }\end{array}$ & $\begin{array}{l}\text { White } \\
\text { leadwort }\end{array}$ & St & 11 & $\begin{array}{l}\text { Whole plants are used for stimulating } \\
\text { palate and digestion and treating } \\
\text { diarrhea, gastric diseases, and herpes- } \\
\text { like skin disorders [8] }\end{array}$ & $39.06 \pm 1.11$ \\
\hline $\begin{array}{l}\text { Glycyrrhiza } \\
\text { glabra L. }\end{array}$ & Leguminosae & $\begin{array}{l}\text { Thinbaw- } \\
\text { nwecho }\end{array}$ & Liquorice & $\mathrm{R}$ & 20 & Undocumented & $58.36 \pm 6.58$ \\
\hline $\begin{array}{l}\text { Cuscuta reflexa } \\
\text { Roxb. }\end{array}$ & Convolvulaceae & Shwe-nwe & Dodder & $\mathrm{WP}$ & 13 & $\begin{array}{l}\text { Whole plants are used to treat } \\
\text { irregularities of the blood. The boiling } \\
\text { liquid of whole plants is used for } \\
\text { inflammation and hardening of the liver. } \\
\text { Whole plants are crushed and pasted for } \\
\text { itches and rashes [8]. }\end{array}$ & $78.83 \pm 3.68$ \\
\hline $\begin{array}{l}\text { Cissampelos } \\
\text { pareira L. }\end{array}$ & Menispermaceae & $\begin{array}{l}\text { Kywet- } \\
\text { nabaung }\end{array}$ & Velvet leaf & $\mathrm{AP}$ & 20 & $\begin{array}{l}\text { Whole plants are pasted for } \\
\text { inflammatory conditions of the eye. } \\
\text { Leaves are used for cooling [8]. }\end{array}$ & $87.71 \pm 3.01$ \\
\hline $\begin{array}{l}\text { Mansonia gagei } \\
\text { J. R. Drumm. }\end{array}$ & Malvaceae & Kala-met & $\begin{array}{c}\text { Bustard } \\
\text { sandalwood }\end{array}$ & W & 4 & $\begin{array}{l}\text { Woods and roots are used to eliminate } \\
\text { phlegm, to treat heart diseases, urinary } \\
\text { disorders, and anemia, and to alleviate } \\
\text { itches [8] }\end{array}$ & $88.91 \pm 0.96$ \\
\hline
\end{tabular}

${ }^{\mathrm{a}}$ L: leaves, AP: aerial parts, W: woods, St: stems, Rh: rhizomes, R: roots, and WP: whole plants. ${ }^{\text {b}}$ Yield $(\%)=($ weight of extract/weight of dry sample) $\times 100$.

reference. After that, they were incubated with $40 \mu \mathrm{g} / \mathrm{mL}$ samples in medium. Insulin $(0.1 \mu \mathrm{mol} / \mathrm{L})$ or berberine $(10 \mu \mathrm{mol} / \mathrm{L})$ was used as positive control. DMSO was added as blank control. After $24 \mathrm{~h}, 10 \mu \mathrm{L}$ medium was taken to measure the glucose concentration by the glucose oxidase method. The experiments were repeated three times. Meanwhile, $20 \mu \mathrm{L}$ MTS was added in the remaining medium of cells and incubated $2 \mathrm{~h}$ at $37^{\circ} \mathrm{C}$. Then, the absorbance at $492 \mathrm{~nm}$ was measured to determine the cytotoxicity of extracts. The value of glucose uptake of the sample was calculated using these formulas:

The glucose concentration $(\mathrm{mmol} / \mathrm{L})=$ sample absorbance/positive control absorbance $\times$ positive control concentration.

Glucose uptake (\% of difference) $=$ (glucose concentration of blank wells - remaining glucose in the cell-plated wells)/glucose concentration of blank wells $\times 100 \%$.

\section{Results}

3.1. PPL Inhibition Activity of Plant Extracts. Twenty-two plant extracts $(100 \mu \mathrm{g} / \mathrm{mL})$ showed the PPL inhibition activity (Table 1 and Table S1). Among them, eight species were tested, with the $\mathrm{IC}_{50}$ values according to PPL inhibition rate higher than 50\% except for Cuscuta sp. in Table 1. Cuscuta sp. showed the PPL inhibition activity with an $\mathrm{IC}_{50}$ value of $93.52 \pm 1.38 \mu \mathrm{g} / \mathrm{mL}$. Cuscuta $s p$. was not properly identified because of morphological characteristics without the flower or fruits. It was found in the same spot where
C. reflexa was discovered. The ethanolic extracts of C. lindenii rhizomes and $A$. indica leaves possessed the highest lipase inhibitory activity with $\mathrm{IC}_{50}$ values of $6.86 \pm 0.25$ and $11.46 \pm 0.06 \mu \mathrm{g} / \mathrm{mL}$, respectively. The ethanolic extracts of $P$. zeylanica stems, G. glabra roots, $C$. pareira aerial parts, M. gagei woods, and C. reflexa whole plants showed moderate lipase inhibitory activity with $\mathrm{IC}_{50}$ values of $37-95 \mu \mathrm{g} / \mathrm{mL}$. Fourteen species showed mild lipase inhibitory activity with $30-47 \%$ inhibition (Supplementary Materials, Table S1).

3.2. Glucose Uptake in 3T3-L1 Adipocytes of Plant Extracts. Seventeen extracts $(40 \mu \mathrm{g} / \mathrm{mL})$ and one plant extract reduced from $40 \mu \mathrm{g} / \mathrm{mL}$ to $20 \mu \mathrm{g} / \mathrm{mL}$ as cytotoxicity to cells of 15 species stimulated glucose uptake in 3T3-L1 adipocytes (Figure 1). The ethnobotanical information and pharmacological properties can be found in Table 2. C. teeta rhizomes and C. tiglium seeds (oily and solid phase) stimulated the highest increase in glucose uptake. At concentration $40 \mu \mathrm{g} / \mathrm{mL}$, their glucose uptakes were higher than positive controls which was insulin $(0.1 \mu \mathrm{M})$ and berberine $(10 \mu \mathrm{M})$. Mahonia sp. and L. cubeba fruits stimulated glucose uptake equivalent to berberine $(10 \mu \mathrm{M}) ; M$. ferrea leaves were close to insulin $(0.1 \mu \mathrm{M})$. The seed extracts of $C$. tiglium and $N$. sativa have oily and solid phase; the two phases were separated to screen the antidiabetic activities. Their oily phase of the extract showed a higher increase in glucose uptake. Mahonia sp. leaves significantly stimulated glucose uptake compared to the control group (Figure 1). The 
TABLE 2: Ethnobotanical information and pharmacological properties of species with stimulating glucose uptake.

\begin{tabular}{|c|c|c|c|c|c|c|}
\hline Scientific name & $\begin{array}{l}\text { Myanmar } \\
\text { name }\end{array}$ & Family & $\operatorname{Part}^{\mathrm{a}}$ & $\begin{array}{c}\text { Yield } \\
(\%)\end{array}$ & Traditional use in Myanmar & Pharmacological properties \\
\hline Croton tiglium L. & $\begin{array}{l}\text { Kanakho, } \\
\text { mai-hkang }\end{array}$ & Euphorbiaceae & $\begin{array}{l}\text { S (oily } \\
\text { phase) }\end{array}$ & 9 & $\begin{array}{l}\text { Oil can be used for stomach } \\
\text { disorders, hypertension, } \\
\text { fever, inflammation, } \\
\text { infections, and diseases of } \\
\text { the throat and ear [8] }\end{array}$ & $\begin{array}{l}\text { Antioxidant, antitumor, anti- } \\
\text { HIV, anticonvulsant, } \\
\text { gastrointestinal, anti- } \\
\text { inflammatory, and } \alpha \text {-amylase } \\
\text { inhibitory activities }[15,16]\end{array}$ \\
\hline Croton tiglium L. & $\begin{array}{l}\text { Kanakho, } \\
\text { mai-hkang }\end{array}$ & Euphorbiaceae & $\begin{array}{l}\text { S (solid } \\
\text { phase) }\end{array}$ & 7 & $\begin{array}{l}\text { To stimulate appetite; } \\
\text { correct imbalances in } \\
\text { phlegm and gas; prevent } \\
\text { jaundice, fainting, and facial } \\
\text { paralysis; also taken as a } \\
\text { laxative to rid the body of } \\
\text { impurities [8] }\end{array}$ & $\begin{array}{l}\text { Antioxidant, antitumor, anti- } \\
\text { HIV, anticonvulsant, } \\
\text { gastrointestinal, anti- } \\
\text { inflammatory, and } \alpha \text {-amylase } \\
\text { inhibitory activities }[15,16]\end{array}$ \\
\hline $\begin{array}{l}\text { Mansonia gagei J.R. } \\
\text { Drumm. }\end{array}$ & Kala-met & Malvaceae & $\mathrm{W}$ & 4 & $\begin{array}{l}\text { To eliminate phlegm; to } \\
\text { treat heart diseases, urinary } \\
\text { disorders, and anemia; to } \\
\text { alleviate itches [8] }\end{array}$ & $\begin{array}{c}\text { Anticancer, antifungal, } \\
\text { antioxidant, and larvicidal } \\
\text { activities }[17,18]\end{array}$ \\
\hline $\begin{array}{l}\text { Litsea cubeba (lour.) } \\
\text { pers. }\end{array}$ & Thing ting & Lauraceae & Fr & 21 & $\begin{array}{l}\text { To treat stomachache and } \\
\text { stomach ulcer; used for } \\
\text { postpartum care [19] }\end{array}$ & $\begin{array}{c}\text { Antimicrobial, anti- } \\
\text { inflammatory, antiasthmatic, } \\
\text { anticholinergic, and antiplatelet } \\
\text { aggregation activities [20] }\end{array}$ \\
\hline $\begin{array}{l}\text { Valeriana jatamansi } \\
\text { jones }\end{array}$ & Kanpalu & Caprifoliaceae & $\mathrm{Rh}$ & 22 & Treating for diabetes & $\begin{array}{l}\text { Analgesic, anti-inflammatory, } \\
\text { myorelaxant and antispasmodic, } \\
\text { psychotic, radioprotective, } \\
\text { antimicrobial, hypnotic, } \\
\text { anthelmintic, cytotoxic, and } \\
\text { antioxidant activities [21] }\end{array}$ \\
\hline $\begin{array}{l}\text { Ligusticum officinale } \\
\text { (makino) kitag. }\end{array}$ & $\begin{array}{l}\text { Kantbalu-u- } \\
\text { thae }\end{array}$ & Apiaceae & $\mathrm{Rh}$ & 12 & Undocumented & $\begin{array}{l}\text { Pancreatic lipase inhibitory, anti- } \\
\text { inflammatory, anticancer, and } \\
\text { antioxidant activities [22] }\end{array}$ \\
\hline Canscora diffusa (vahl) & & & & & & \\
\hline $\begin{array}{l}\text { R.Br. ex roem. and } \\
\text { schult. }\end{array}$ & Kyauk-pan & Gentianaceae & $\mathrm{L}$ & 19 & Undocumented & Antibacterial activities [23] \\
\hline $\begin{array}{l}\text { Caladium lindenii } \\
\text { (andré) madison }\end{array}$ & $\begin{array}{l}\text { Gamone- } \\
\text { gya }\end{array}$ & Araceae & $\mathrm{Rh}$ & 21 & Undocumented & Not reported \\
\hline $\begin{array}{l}\text { Zingiber officinale } \\
\text { roscoe }\end{array}$ & Gyin & Zingiberaceae & $\mathrm{Rh}$ & 11 & $\begin{array}{l}\text { Laryngitis, chest and } \\
\text { respiratory ailments, } \\
\text { infected sores, and } \\
\text { inflammation caused by } \\
\text { injury [8] }\end{array}$ & $\begin{array}{c}\text { Antidiabetic, antithrombotic, } \\
\text { anti-inflammatory, analgesic, } \\
\text { antioxidant, and antimicrobial } \\
\text { activities }[24]\end{array}$ \\
\hline Nigella sativa $L$. & Samon-net & Ranunculaceae & $\begin{array}{l}\text { S (oily } \\
\text { phase) }\end{array}$ & 3 & $\begin{array}{l}\text { Carminative and } \\
\text { galactagogue [8] }\end{array}$ & $\begin{array}{l}\text { Antimicrobial, antioxidant, } \\
\text { antihyperlipidemic, anticancer, } \\
\text { antidiabetic, gastroprotective, } \\
\text { nephroprotective, and } \\
\text { hepatoprotective activities [25] }\end{array}$ \\
\hline Nigella sativa $L$. & Samon-net & Ranunculaceae & $\begin{array}{l}\text { S (solid } \\
\text { phase) }\end{array}$ & 12 & $\begin{array}{c}\text { Used as a carminative and } \\
\text { galactagogue [8] }\end{array}$ & $\begin{array}{l}\text { Antimicrobial, antioxidant, anti- } \\
\text { inflammatory, } \\
\text { antihyperlipidemic, anticancer, } \\
\text { antidiabetic, cardiovascular } \\
\text { protective, gastroprotective, } \\
\text { nephroprotective, } \\
\text { hepatoprotective, wound-healing } \\
\text { activities, the effect on the } \\
\text { reproductive system, and } \\
\text { immunoprotective activity [25] }\end{array}$ \\
\hline $\begin{array}{l}\text { Baliospermum } \\
\text { solanifolium (Burm.) } \\
\text { Suresh }\end{array}$ & $\begin{array}{l}\text { Hnat-cho, } \\
\text { ya-wo-mo, } \\
\text { ya-wo-po }\end{array}$ & Euphorbiaceae & St & 4 & Toothache, purge & $\begin{array}{l}\text { Roots have anticancer, } \\
\text { immunomodulatory, anti- } \\
\text { inflammatory, antioxidant, and } \\
\text { hepatoprotective activities [26] }\end{array}$ \\
\hline
\end{tabular}


TABLE 2: Continued.

\begin{tabular}{|c|c|c|c|c|c|c|}
\hline Scientific name & $\begin{array}{l}\text { Myanmar } \\
\text { name }\end{array}$ & Family & $\operatorname{Part}^{\mathrm{a}}$ & $\begin{array}{c}\text { Yield } \\
(\%)\end{array}$ & Traditional use in Myanmar & Pharmacological properties \\
\hline $\begin{array}{l}\text { Pterocarpus indicus } \\
\text { Willd. }\end{array}$ & Pan-padauk & Leguminosae & W & 5 & Dysentery, diarrhea & $\begin{array}{c}\text { Barks showed } \alpha \text {-glucosidase } \\
\text { inhibitory activity [27], } \\
\text { antitumor and antibacterial } \\
\text { activity, and antiallergic } \\
\text { properties [28] }\end{array}$ \\
\hline Coptis teeta Wall. & Khan tauk & Ranunculaceae & $\mathrm{R}$ & 23 & $\begin{array}{l}\text { To relieve constipation, } \\
\text { regulate bowel movements, } \\
\text { promote digestion, reduce } \\
\text { fever, treat malaria, and } \\
\text { increase vitality; roots } \\
\text { soaked in liquor for malaria } \\
\text { [8] }\end{array}$ & $\begin{array}{l}\text { Antipathogenic microorganism, } \\
\text { antidiabetes, and anticancer } \\
\text { activities; protective effects on the } \\
\text { cardiovascular system [29] }\end{array}$ \\
\hline Mesua ferrea $L$. & Guntgaw & Calophyllaceae & $\mathrm{L}$ & 12 & To treat snakebites $[8]$ & $\begin{array}{c}\text { Analgesic and antibacterial } \\
\text { activities [30] }\end{array}$ \\
\hline $\begin{array}{l}\text { Hesperethusa crenulata } \\
\text { (Roxb.) Roem. }\end{array}$ & $\begin{array}{l}\text { Sansph-ka, } \\
\text { Thanaka }\end{array}$ & Rutaceae & $\mathrm{R}$ & 9 & $\begin{array}{l}\text { Barks are used as a skincare } \\
\qquad[31] .\end{array}$ & $\begin{array}{l}\text { Barks showed antioxidant, anti- } \\
\text { inflammatory, and tyrosinase } \\
\text { inhibitory activities [31]; leaves } \\
\text { showed tyrosinase inhibitory } \\
\text { activity [32] }\end{array}$ \\
\hline $\begin{array}{l}\text { Hesperethusa crenulata } \\
\text { (Roxb.). Roem. }\end{array}$ & $\begin{array}{l}\text { Sansph-ka, } \\
\text { Thanaka }\end{array}$ & Rutaceae & $\mathrm{L}$ & 5 & $\begin{array}{c}\text { Barks are used as a skincare } \\
{[31] .}\end{array}$ & $\begin{array}{l}\text { Barks showed antioxidant, anti- } \\
\text { inflammatory, and tyrosinase } \\
\text { inhibitory activities [31]; leaves } \\
\text { showed tyrosinase inhibitory } \\
\text { activity [32] }\end{array}$ \\
\hline
\end{tabular}

${ }^{\mathrm{a}} \mathrm{S}$ : seeds, L: leaves, R: roots, Rh: rhizomes, W: woods, WP: whole plants, St: stems, and Fr: fruits.

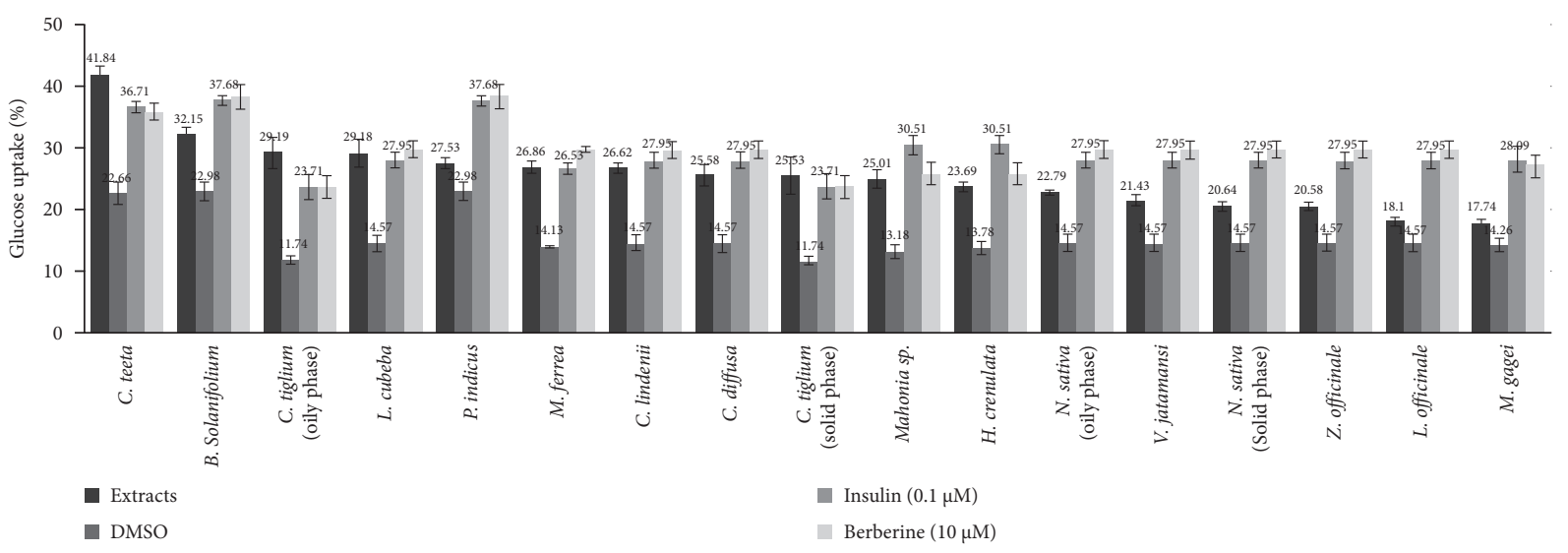

FIGURE 1: The effects 17 extracts $(40 \mu \mathrm{g} / \mathrm{mL})$ of 15 plant species on glucose uptake of 3T3-L1 adipocytes. Data is represented as percentage of glucose uptake, in comparison to the control group (DMSO) and positive control (insulin and berberine).

concentration was lowered to $20 \mu \mathrm{g} / \mathrm{mL}$ for glucose uptake test as the root extracts of $H$. crenulata showed cytotoxicity against adipocytes at $40 \mu \mathrm{g} / \mathrm{mL}$. H. crenulata root significantly increased glucose uptake with the value of glucose uptake $(21.81 \pm 2.49) \%$ at $20 \mu \mathrm{g} / \mathrm{mL}$ compared to the control group $(9.31 \pm 1.34) \%$; the value of insulin $(0.1 \mathrm{M})$ and berberine glucose uptake $(10 \mathrm{M})$ were $(28.95 \pm 1.16) \%$ and $(25.72 \pm 1.45)$ $\%$. This information was not mentioned in Figure 1.

\subsection{Research Progress on Antidiabetic Activities of Medicinal} Plants. To make clear the antidiabetic medicines for further study, the research status of medicinal plants in antidiabetes was reported in Supplementary Materials (Table S2) from traditional use to clinical research including traditional use, in vitro assay, in vivo animal studies, and clinical trials. The antidiabetic evidence of relative plants can be found in the Supplement Materials (Table S3).

In our research, extracts $(100 \mu \mathrm{g} / \mathrm{mL})$ of 22 species showed the PPL inhibition activity; 17 extracts $(40 \mu \mathrm{g} / \mathrm{mL})$ and one plant extract reduced from $40 \mu \mathrm{g} / \mathrm{mL}$ to $20 \mu \mathrm{g} / \mathrm{mL}$ as cytotoxicity to cells of 15 species stimulated glucose uptake in 3T3-L1 adipocytes. Among them, Caladium lindenii (André) Madison, Mansonia gagei J.R. Drumm., and Mesua ferrea L. possessed both activities (Figure 2(a)). Crateva religiosa G. Forst., Antidesma acidum Retz., and Coptis teeta 


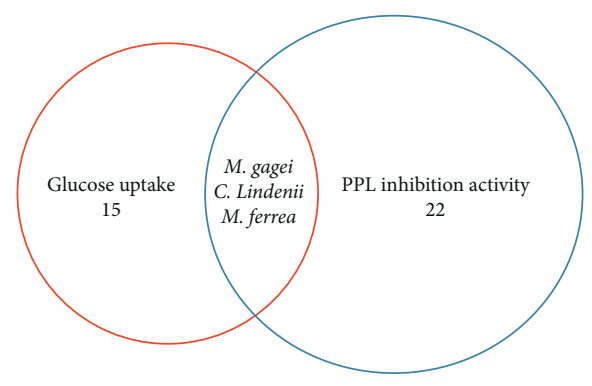

(a)

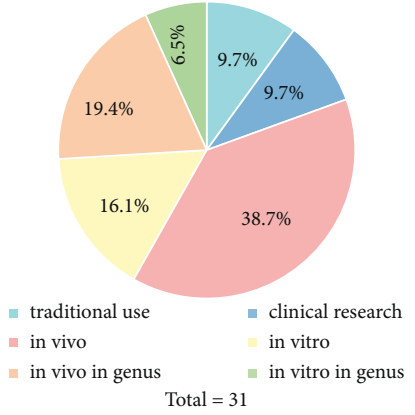

(b)

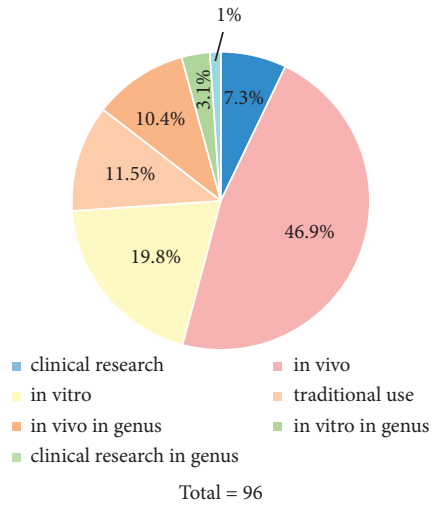

(c)

Figure 2: (a) The species possessed the PPL inhibition activity and stimulated glucose uptake in 3T3-L1 adipocytes. (b) Research status of traditional plants showing antidiabetic activities in our study. (c) Research status of extracted antidiabetic plants.

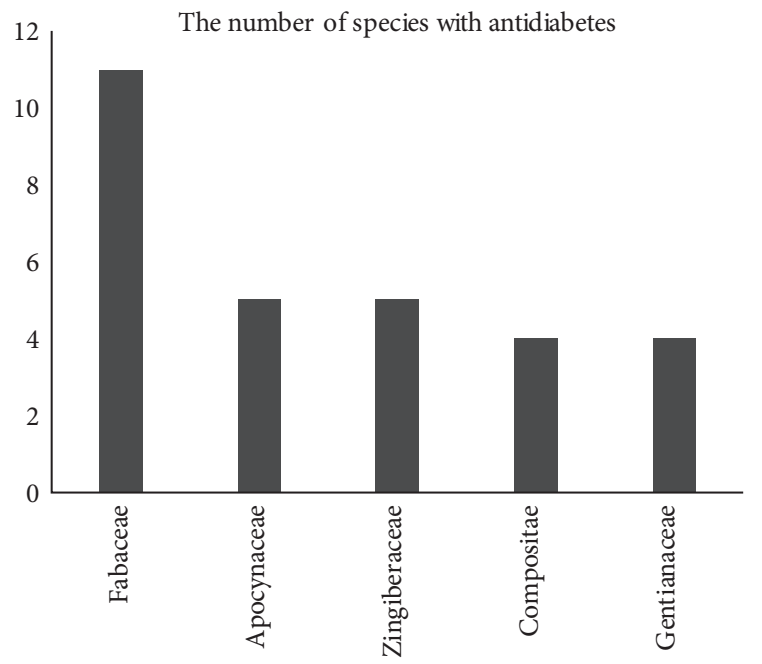

Figure 3: Top five plant families reported for antidiabetic properties by survey.

Wall. were the only reported traditional use for treating diabetes without any report on antidiabetic activity that accounted for $10 \%$ of research status (Figure 2(b)). Here, Hesperethusa crenulata (Roxb.) M. Roem., M. gagei, A. acidum, Eriobotrya bengalensis Kurz., C. lindenii, Ligusticum officinale (Makino) Kitag., Cajanus volubilis (King) Maesen, Canscora diffusa (Vahl) R.Br. ex Roem. and Schult., Canscora andrographioides Griff. ex C.B. Clarke, and Pterocarpus indicus Willd. were reported for their antidiabetic activities for the first time.

There are 82 species of 51 families and 14 species in the genus with antidiabetic properties so that they have high diversity (Supplementary Material, Tables S2 and S3). The Fabaceae family had the largest number of species showed antidiabetic activity (Figure 3). Among them, 7.3\% species were already studied in type 2 diabetic patients, $46.9 \%$ species were researched antidiabetic activities in vivo, and $11.5 \%$ species were only recorded traditional use without any reported pharmacological activities on antidiabetes (Figure 2(c)).

3.4. A Literature Review of Antidiabetic Compounds from Selected Medicinal Plants in Myanmar. Forty of the 82 species were reported antidiabetic components with various types including terpenes, alkaloids, flavonoids, lignans, and other types (Figure S1). Among them, flavonoids (28 compounds) and triterpenoids (26 compounds) are the dominant compounds accounting for $61.4 \%$. Flavonoids were mainly reported $\alpha$-glucosidase inhibition and PPAR$\gamma$-ligand-binding activities. They are found in Oroxylum indicum, Eclipta prostrata, Nigella sativa, Glycyrrhiza glabra, Senna siamea, Boesenbergia rotunda, and Cinnamomum tamala. PPAR- $\gamma$-ligand-binding activities in phenolic compounds are affected by the slight differences of substitution groups on the aromatic rings [33].

The primary targets of antidiabetic triterpenoids were $\alpha$-glucosidase inhibition and lipolytic activity in 3T3-L1 adipocytes. Triterpenoids were isolated from Abrus precatorius, Plumeria rubra, Pongamia pinnata, Entada phaseoloides, Eclipta prostrata, Lagerstroemia speciosa, Trigonella foenum-graecum, Centella asiatica, Brucea javanica. Lupane skeleton and a ketone at C-3 of triterpenes would be essential for exerting a potent PPA inhibition in A. precatorius [34]. Triterpenoid glycosides having glucopyranosyl moiety are favorable for inhibiting PTP1B enzyme from E. prostrata [35]. Bitter-taste receptors of quassinoids may be a target as to induce lipolytic activity, the length of acyl side chain at $15-\mathrm{OH}$ is important for the lipolytic activity of B. javanica [36].

\section{Discussion}

The potential species were discussed from pharmacological activities and safety extracts were with $\mathrm{IC}_{50}<50 \mu \mathrm{g} / \mathrm{mL}$ in PPL inhibition, higher or closely positive in glucose uptake, or showed these two activities. 
H. crenulata is known as Thanaka, and the stem bark powder is used as a skincare regiment over one thousand years in Myanmar [31]. It is also a common tropical plant species in the Indian subcontinent and Southeast Asia with various medicinal properties, such as purgative, antidote, stomachic, and sudorific [31]. Coumarins and sitosterol were found in its root bark [37]. Extracts from Thanaka bark showed strong anti-inflammatory, significant antioxidation, and mild tyrosinase inhibition without detectable genotoxicity [31]. We reported the antidiabetic activities of its roots and barks for the first time.

The heartwood of M. gagei showed antibacterial, antifungal, and antioxidant activities [12, 17]. The chemical constitutes of $M$. gagei revealed antiestrogenic, antifungal, and antioxidant, and anticancer activities [17, 18]. Coumarins and mansonones are the main constituents and active ingredients in $M$. gagei $[17,18,38,39]$. Its antidiabetic activities were reported for the first time which was proved with PPL inhibition and increase the glucose uptake to deserve further study about the activity in vivo and its safety.

The tuber of $C$. lindenii was used for Stingray wounds in Brazil [40]. The phytochemical investigation of Caladium indicated flavonoids, alkaloids, saponins, cardiac glycosides, carbohydrates, and deoxy sugars [41]. There is no reported research about the phytochemical and pharmacological research of $C$. lindenii. The corm of C. bicolor showed stimulation of glucose uptake in adipocytes and hepatoprotective activity in Hep G2 cells [42]. Methanol leaf extract of C. bicolor showed toxicity to the kidney but no adverse effect on the heart, lungs, spleen, liver, and brain [43].

A. indica, known as neem, is a common traditional medicine for the treatment with diabetes mellitus in Africa and India $[44,45]$. At 25, 48.4, 93.5, 180.9, and $350 \mathrm{mg} / \mathrm{kg}$ body weight, intraperitoneal and oral administration of aqueous leaf extract of $A$. indica decreased the blood glucose levels in alloxan-induced diabetic mice but not in a dose-related manner [44]. Ten ligands of neem possessed binding properties with T2DM protein enzyme target phosphoenolpyruvate carboxykinase; compound 3-deacetyl3-cinnamoyl-azadirachtin showed the best binding [46]. Meliacinolin possessed $\alpha$-glucosidase and $\alpha$-amylase inhibition activities with $\mathrm{IC}_{50} 46.7$ and $32.2 \mu \mathrm{g} / \mathrm{mL}$ from chloroform extract of $A$. indica leaves. And orally administered meliacinolin $(20 \mathrm{mg} / \mathrm{kg}$ body weight) could be able to revert a set of biochemical parameters of streptozotocin STZ-diabetic mice to respective normal values and its mechanism was deduced via its insulinogenic action [45]. Braga et al. reviewed the safety of $A$. indica extracts and/or isolated compounds and revealed nontoxicity or less toxicity when orally administered but had acute toxicity by intramuscular injection or via the intraperitoneal route [47].

The roots and leaves of $P$. zeylanica are traditionally used to treat diabetes in India and China $[48,49]$. The ethanol extracts of $P$. zeylanica stem inhibited porcine pancreatic lipase activity with $\mathrm{IC}_{50} 39.1 \mu \mathrm{g} / \mathrm{mL}$ (Table 1). Oral administration of ethanolic extract of $P$. zeylanica roots $(100$ and $200 \mathrm{mg} / \mathrm{kg}$ ) decreased blood and urine glucose levels, increased hepatic hexokinase activity, and decreased hepatic glucose-6-phosphatase, serum acid phosphatase, alkaline phosphatase, and lactate dehydrogenase in streptozotocin STZ-diabetic rats [50]. Plumbagin is the major bioactive component for antidiabetic activity ( 15 and $30 \mathrm{mg} / \mathrm{kg}$ body weight) by reducing blood glucose and returning other biochemical parameters to normal and enhancing GLUT4 $\mathrm{mRNA}$, protein expression in diabetic rats from P. zeylanica root. The antidiabetic effect is lower than glibenclamide $(4 \mathrm{mg} / \mathrm{kg})$ [49]. Oral administration of aqueous extract was found to be safe up to the dose of $2000 \mathrm{mg} / \mathrm{kg}$ during the 14 days of observation by acute toxicity profile experiment [51].

The rhizome of $C$. teeta along with $C$. chinensis and C. deltoidea is known as "coptidis rhizome" which has been widely used to treat bacillary dysentery, diabetes, pertussis, sore throat, aphtha, and eczema in China [29]. C. chinensis polysaccharide ( $200 \mathrm{mg} / \mathrm{kg}$ body weight) showed significant inhibition in fasting blood glucose level and triglycerides [52]. Alkaloids are the most abundant components and are considered as the main active ingredients [29]. The methanol extract of C. chinensis rhizome significantly inhibits adipocyte differentiation and lipid contents in 3T3-L1 cells. Five alkaloids, berberine, epiberberine, coptisine, palmatine, and magnoflorine were significantly inhibited lipid accumulation in 3T3-L1 cells without affecting cell viability and reduced the expression levels of several adipocyte marker genes including proliferator-activated receptor- $\gamma$ (PPAR- $\gamma$ ) and CCAAT/enhancer-binding protein- $\alpha$ (C/EBP- $\alpha)$ from methanol extract of $C$. chinensis rhizome [53]. (3ß)-Stigmast-5-en-3-ol stimulates glucose uptake by the PI3K-dependent pathway in L6 myotubes and activates GLUT 4 transport $[54,55]$. Berberine was the main compound from the ethanol extract of C. teeta rhizome [54]. Lan et al. extracted 27 clinical trials (2569 patients) and revealed berberine with comparable therapeutic effects on T2DM, hyperlipidemia, and hypertension with no serious adverse reactions [56].

C. tiglium seeds were traditionally used for stimulating appetite, imbalances in phlegm and gas, jaundice, fainting, and facial paralysis and taken as a laxative to rid the body of impurities in Myanmar. The seeds oil can be used for stomach disorders, hypertension, fever, inflammation, infections, and diseases of the throat and ear [8]. C. cajucara, C. macrostachys, and C. malambo were used to cure diabetes [57]. The extract of C. tiglium inhibited $\alpha$-amylase with $55.1 \%$ at $80 \mu \mathrm{g} / \mathrm{mL}$ [16]. Oral medication can cause severe gastrointestinal syndrome and even mortality because of irritating oils and croton proteins [58]. Tigliane-type diterpenoids are the predominant secondary metabolite constituents in C. tiglium L. [59].

The raw fruits of $L$. cubeba were traditionally used to prevent and check for hyperglycemia in India. Its methanol extract inhibited $\alpha$-amylase and $\alpha$-glucosidase with $\mathrm{IC}_{50}$ values of $514.9 \mu \mathrm{g} / \mathrm{mL}$ and $1,435.7 \mu \mathrm{g} / \mathrm{mL}$, respectively. Its ethanol extracts exhibited lower inhibition activity. Phenols and flavonoids were the major phytochemicals in different extracts against diabetes [60]. L. cubeba oil was proved with slightly toxic that the oral $\mathrm{LD}_{50}$, dermal $\mathrm{LD}_{50}$, and inhalation $\mathrm{LC}_{50}$ values were approximately $4,000 \mathrm{mg} / \mathrm{kg}$ of body weight [61]. 
The buds of $M$. ferrea displayed the mild inhibition on $\alpha$-glucosidase and $\alpha$-amylase activity with $\mathrm{IC}_{50}$ values of $128.8 \mu \mathrm{g} / \mathrm{mL}$ and $146.8 \mu \mathrm{g} / \mathrm{mL}$, respectively $[62,63]$. Stamens of $M$. ferrea produced a dose-dependent reduction in blood sugar (hypoglycemia) at a dose of 150 and $300 \mathrm{mg} / \mathrm{kg}$ body weight in alloxan-induced diabetic rats [64]. The methanol extract of $M$. ferrea flower has shown the antidiabetic activity in streptozotocin-induced diabetic rats and deduced the mechanism [65]. The extract of $M$. ferrea flower was proved no acute toxicity in an animal model but exhibited mild lymphocytic infiltration and hepatocyte degeneration $[65,66]$. Xanthones and coumarins are predominantly secondary metabolites from Mesua species which display antitumor and antimicrobial, antioxidant, anti-inflammatory, or immunomodulating properties [67]. However, there is not any research reported related with antidiabetic activity of its leaves previously.

\section{Conclusion}

L. cubeba, H. crenulate, and $M$. gagei deserve further study because of the potential antidiabetic activity in in vitro assay and unclear active ingredients and mechanism along with research about antidiabetic effects in in vivo animal studies and unclarity in safety except for L. cubeba with slightly toxic activity. Moreover, C. teeta, P. zeylanica, and M. ferrea are also worth giving attention as the low toxicity and antidiabetic activities of these species or its genus level in research status. The antidiabetic activities and their constitutes of M. ferrea are studied in our research.

\section{Data Availability}

The data used to support the findings of this study are included within the Supplementary Materials.

\section{Conflicts of Interest}

The authors declare that they have no conflicts of interest regarding the publication of this paper.

\section{Authors' Contributions}

Ethnobotanical survey was done by Dongdong Zhang, Yu Zhang, Jun Yang, Pyae Phyo Hein, Aye Mya Mon, and Jianwen Li; specimen identification was performed by $\mathrm{Yu}$ Zhang and Jun Yang; Wang Yuehu and Xuefei Yang designed the study; experiment, analysis, and interpretation of the data and drafting of the manuscript were done by Dongdong Zhang; critical revision of the manuscript was performed by Wang Yuehu, Karuppusamy Arunachalam, Dongdong Zhang, Angkhana Inta, and Xuefei Yang.

\section{Acknowledgments}

The porcine pancreatic lipase (PPL) inhibition assay and glucose uptake in 3T3-L1 adipocytes assay were performed by the Service Center for Bioactivity Screening, Kunming Institute of Botany. This research was supported by the Southeast Asia Biodiversity Research Institute, Chinese
Academy of Sciences in China (Grants nos. 2015CASEABRIRG001 and Y4ZK111B01) and the National Natural Science Foundation of China (Grant no. 31770368).

\section{Supplementary Materials}

Table S1. Information with 30-50\% PPL inhibition activities of 17 medicinal plants. Table S2. 82 species of 51 families with antidiabetic properties research status. Table S3. Relative plants in antidiabetic reports without any antidiabetes research. Table S4. The information of antidiabetic ingredients. Figure S1. Antidiabetic components from medicinal plants in Myanmar. (Supplementary Materials)

\section{References}

[1] A. Chaudhury, C. Duvoor, V. S. Reddy Dendi et al., "Clinical review of antidiabetic drugs: implications for type 2 diabetes mellitus management," Frontiers in Endocrinology, vol. 8, p. 6, 2017.

[2] Y. Zheng, S. H. Ley, and F. B. Hu, "Global aetiology and epidemiology of type 2 diabetes mellitus and its complications," Nature Reviews Endocrinology, vol. 14, no. 2, pp. 88-98, 2018.

[3] M. Ali Asgar, "Anti-diabetic potential of phenolic compounds: a review," International Journal of Food Properties, vol. 16, no. 1, pp. 91-103, 2012.

[4] N. A. Lunagariya, N. K. Patel, S. C. Jagtap, and K. K. Bhutani, "Inhibitors of pancreatic lipase: state of the art and clinical perspectives," EXCLI journal, vol. 13, pp. 897-921, 2014.

[5] M. P. Czech, "Insulin action and resistance in obesity and type 2 diabetes," Nature Medicine, vol. 23, no. 7, pp. 804-814, 2017.

[6] J. Lakshmanan, J. S. Elmendorf, and S. Özcan, Analysis of Insulin-Stimulated Glucose Uptake in Differentiated 3T3-L1 Adipocytes, Humana Press, Totowa, NJ, USA, 2003.

[7] H. M. Manukumar, J. Shiva Kumar, B. Chandrasekhar, S. Raghava, and S. Umesha, "Evidences for diabetes and insulin mimetic activity of medicinal plants: present status and future prospects," Critical Reviews in Food Science and Nutrition, vol. 57, no. 12, pp. 2712-2729, 2017.

[8] R. A. DeFilipps and G. A. Krupnick, "The medicinal plants of Myanmar," PhytoKeys, vol. 102, 2018.

[9] 2007 Nyunt T., Kyaw U. A. M., Nyunt U. T et al.... Medicinal plants of Myanmar. In: Medicine Mohdot ed.

[10] M. Z. Aumeeruddy and M. F. Mahomoodally, "Ethnomedicinal plants for the management of diabetes worldwide: a systematic review," Current Medicinal Chemistry, vol. 28, no. 23, pp. 4670-4693, 2021.

[11] Q. L. Tran, Q. K. Tran, K. Kouda et al., "Investigation on traditional medicine in Myanmar and Vietnam," Journal of Traditional Medicines, vol. 20, pp. 173-186, 2003.

[12] T. H. Li, D. D. Zhang, T. N. Oo et al., "Investigation on the antibacterial and anti-T3SS activity of traditional Myanmar medicinal plants. Evidence-based complementary and alternative medicine," Evidence-Based Complementary and Alternative Medicine, vol. 2018, Article ID 2812908, 13 pages, 2018.

[13] J. H. Kim, H. J. Kim, H. W. Park, S. H. Youn, D.-Y. Choi, and C. S. Shin, "Development of inhibitors against lipase and Î̀-glucosidase from derivatives of monascus pigment," FEMS Microbiology Letters, vol. 276, no. 1, pp. 93-98, 2007. 
[14] L. Zhou, Y. Yang, X. Wang et al., "Berberine stimulates glucose transport through a mechanism distinct from insulin," Metabolism, vol. 56, no. 3, pp. 405-412, 2007.

[15] S. Sinsinwar, I. Paramasivam, and M. S. Muthuraman, "An overview of the biological and chemical perspectives of Croton tiglium," Scholars Research Library, vol. 8, pp. 324-328, 2016.

[16] V. P. Karthik, P. Punnagai, and P. Suresh, "In Vitro hydrogen peroxide scavenging activity and alpha amylase inhibitory activity of Croton tiglium extract," Research Journal of Pharmacy and Technology, vol. 12, no. 6, pp. 3045-3047, 2019.

[17] P. Tiew, J.-R. Ioset, U. Kokpol, W. Chavasiri, and K. Hostettmann, "Antifungal, antioxidant and larvicidal activities of compounds isolated from the heartwood of Mansonia gagei," Phytotherapy Research, vol. 17, no. 2, pp. 190-193, 2003.

[18] M. A. Baghdadi, F. A. Al-Abbasi, A. M. El-Halawany, A. H. Aseeri, and A. M. Al-Abd, "Anticancer profiling for coumarins and related O-naphthoquinones from Mansonia gagei against solid tumor cells in vitro," Molecules, vol. 23, 2018.

[19] H. G. Ong, S. M. Ling, T. T. M. Win, D.-H. Kang, J.-H. Lee, and Y.-D. Kim, "Ethnobotany of wild medicinal plants used by the Müün ethnic people: a quantitative survey in southern Chin state, Myanmar," Journal of Herbal Medicine, vol. 13, pp. 91-96, 2018.

[20] D.-G. Kong, Y. Zhao, G.-H. Li et al., "The genus Litsea in traditional Chinese medicine: an ethnomedical, phytochemical and pharmacological review," Journal of Ethnopharmacology, vol. 164, pp. 256-264, 2015.

[21] V. S. Devi and M. G. Rao, "Valeriana wallichii-a rich aroma root plant," World Journal of Pharmacy and Pharmaceutical Sciences, vol. 3, pp. 1516-1525, 2014.

[22] E. J. Mo, H. J. Yang, J. Y. Jeong et al., "Pancreatic lipase inhibitory phthalide derivatives from the rhizome of Cnidium officinale," Records of Natural Products, vol. 10, p. 148, 2016.

[23] Y. Mahida and J. S. S. Mohan, "Screening of Indian plant extracts for antibacterial activity," Pharmaceutical Biology, vol. 44, no. 8, pp. 627-631, 2008.

[24] B. H. Ali, G. Blunden, M. O. Tanira, and A. Nemmar, "Some phytochemical, pharmacological and toxicological properties of ginger (Zingiber officinale Roscoe): a review of recent research," Food and Chemical Toxicology, vol. 46, no. 2, pp. 409-420, 2008.

[25] K. Wesam, H. N. Zahra, S. A. Naim, A. S. Majid, and A. L. Damoon, "Phytochemistry, pharmacology, and therapeutic uses of black seed (Nigella sativa)," Chinese Journal of Natural Medicines, vol. 14, pp. 732-745, 2016.

[26] R. Mali and R. Wadekar, "Baliospermum montanum (Danti): ethnobotany, phytochemistry and pharmacology- A review," International Journal of Green Pharmacy, vol. 2, no. 4, pp. 194-199, 2008.

[27] J. Sichaem, S. Tip-pyang, K. Lugsanangarm, and R. Jutakanoke, "Highly potent $\alpha$-glucosidase inhibitors from Pterocarpus indicus and molecular docking studies," Songklanakarin Journal of Science and Technology, vol. 72, pp. 426, 2018.

[28] H.-S. Cha, W.-J. Kim, M.-H. Lee et al., "Inhibitory effect of Pterocarpus indicus Willd water extract on IgE/Ag-induced mast cell and atopic dermatitis-like mouse models," Bioscience, Biotechnology, and Biochemistry, vol. 80, no. 5, pp. 911-919, 2016.

[29] J. Wang, L. Wang, G.-H. Lou et al., "Coptidis Rhizoma: a comprehensive review of its traditional uses, botany, phytochemistry, pharmacology and toxicology," Pharmaceutical Biology, vol. 57, no. 1, pp. 193-225, 2019.

[30] K. Chahar and L. Mesua ferrea, "Mesua ferrea L.: a review of the medical evidence for its phytochemistry and pharmacological actions," African Journal of Pharmacy and Pharmacology, vol. 7, no. 6, pp. 211-219, 2013.

[31] S. Wangthong, T. Palaga, S. Rengpipat, S. P. Wanichwecharungruang, P. Chanchaisak, and M. Heinrich, "Biological activities and safety of Thanaka (Hesperethusa crenulata) stem bark," Journal of Ethnopharmacology, vol. 132, no. 2, pp. 466-472, 2010.

[32] Myint K. Z. W.. Phytochemical and in Vitro Biological Studies on Myanmar Medicinal Plants for Functional Food and Cosmetic Applications.

[33] M. Kuroda, Y. Mimaki, S. Honda, H. Tanaka, S. Yokota, and T. Mae, "Phenolics from Glycyrrhiza glabra roots and their PPAR- $\gamma$ ligand-binding activity," Bioorganic \& Medicinal Chemistry, vol. 18, no. 2, pp. 962-970, 2010.

[34] R. Yonemoto, M. Shimada, M. D. P. T. Gunawan-Puteri, E. Kato, and J. Kawabata, " $\alpha$-amylase inhibitory triterpene from Abrus precatorius leaves," Journal of Agricultural and Food Chemistry, vol. 62, no. 33, pp. 8411-8414, 2014.

[35] D. D. Le, D. H. Nguyen, E. S. Ma et al., "PTP1B inhibitory and anti-inflammatory properties of constituents from Eclipta prostrata L," Biological and Pharmaceutical Bulletin, vol. 44, no. 3, pp. 298-304, 2021.

[36] L. Lahrita, K. Moriai, R. Iwata, K. Itoh, and E. Kato, "Quassinoids in Brucea javanica are potent stimulators of lipolysis in adipocytes," Fitoterapia, vol. 137, Article ID 104250, 2019.

[37] M. N. S. Nayar and M. K. Bhan, "Coumarins and other constituents of Hesperethusa crenulata," Phytochemistry, vol. 11, no. 11, pp. 3331-3333, 1972.

[38] P. Tiew, A. Puntumchai, U. Kokpol, and W. Chavasiri, "Coumarins from the heartwoods of Mansonia gagei drumm," Phytochemistry, vol. 60, no. 8, pp. 773-776, 2002.

[39] R. Mongkol and W. Chavasiri, "Antimicrobial, herbicidal and antifeedant activities of mansonone $\mathrm{E}$ from the heartwoods of Mansonia gagei Drumm," Journal of Integrative Agriculture, vol. 15, no. 12, pp. 2795-2802, 2016.

[40] M. Coelho-Ferreira, "Medicinal knowledge and plant utilization in an Amazonian coastal community of Marudá, Pará State (Brazil)," Journal of Ethnopharmacology, vol. 126, no. 1, pp. 159-175, 2009.

[41] E. E. Essien, I. E. Jacob, and P. S. Thomas, "Phytochemical composition, antimicrobial and antioxidant activities of leaves and tubers of three Caladium species," International Journal of Medicinal Plants and Natural Products, vol. 1, pp. 24-30, 2015.

[42] J. R. Abima Shazhni, A. Renu, and P. Vijayaraghavan, "Insights of antidiabetic, anti-inflammatory and hepatoprotective properties of antimicrobial secondary metabolites of corm extract from Caladium x hortulanum," Saudi Journal of Biological Sciences, vol. 25, no. 8, pp. 17551761, 2018.

[43] A. M. Akhigbemen, R. I. Ozolua, E. E. Bafor, and E. O. Okwuofu, "Subacute toxicological profile of Caladium bicolor Aiton (Araceae) methanolic leaf extract in rat," Journal of Pharmacy \& Pharmacognosy Research, vol. 6, pp. 503-516, 2018.

[44] W. M. Arika, D. W. Nyamai, D. S. Agyirifo, M. P. Ngugi, and E. N. M. Njagi, "In vivo antidiabetic effect of aqueous leaf extract of Azardirachta indica A. juss in alloxan induced 
diabetic mice," Journal of Diabetic Complications and Medicine, vol. 1, pp. 1-6, 2016.

[45] R. M. Perez-Gutierrez and M. Damian-Guzman, "Meliacinolin: a potent $\alpha$-glucosidase and $\alpha$-amylase inhibitor isolated from Azadirachta indica leaves and in vivo antidiabetic property in streptozotocin-nicotinamide-induced type 2 diabetes in mice," Biological \& Pharmaceutical Bulletin, vol. 35, no. 9, pp. 1516-1524, 2012.

[46] A. Jalil, U. A. Ashfaq, U. A. Ashfaq et al., "Screening and design of anti-diabetic compounds sourced from the leaves of neem (Azadirachta indica)," Bioinformation, vol. 9, no. 20, pp. 1031-1035, 2013.

[47] T. M. Braga, L. Rocha, T. Y. Chung et al., "Azadirachta indica A. Juss. In vivo toxicity-an updated review," Molecules, vol. 26, 2021.

[48] M. Goyal, "Traditional plants used for the treatment of diabetes mellitus in Sursagar constituency, Jodhpur, Rajasthan an ethnomedicinal survey," Journal of Ethnopharmacology, vol. 174, pp. 364-368, 2015.

[49] C. Sunil, V. Duraipandiyan, P. Agastian, and S. Ignacimuthu, "Antidiabetic effect of plumbagin isolated from Plumbago zeylanica L. root and its effect on GLUT4 translocation in streptozotocin-induced diabetic rats," Food and Chemical Toxicology, vol. 50, no. 12, pp. 4356-4363, 2012.

[50] M. M. Zarmouh, K. Subramaniyam, S. Viswanathan, and P. G. Kumar, "Cause and effect of Plumbago zeylanica root extract on blood glucose and hepatic enzymes in experimental diabetic rats," African Journal of Microbiology Research, vol. 4, pp. 2674-2677, 2010.

[51] S. R. Pendurkar and S. A. Mengi, "Antihyperlipidemic effect of aqueous extract ofPlumbago zeylanicaroots in diet-induced hyperlipidemic rat," Pharmaceutical Biology, vol. 47, no. 10, pp. 1004-1010, 2009.

[52] S. Jiang, Y. Wang, D. Ren et al., "Antidiabetic mechanism ofCoptis chinensispolysaccharide through its antioxidant property involving the JNK pathway," Pharmaceutical Biology, vol. 53, no. 7, pp. 1022-1029, 2015.

[53] J. S. Choi, J.-H. Kim, M. Y. Ali, B.-S. Min, G.-D. Kim, and H. A. Jung, "Coptis chinensis alkaloids exert anti-adipogenic activity on 3T3-L1 adipocytes by downregulating C/EBP- $\alpha$ and PPAR- $\gamma$," Fitoterapia, vol. 98, pp. 199-208, 2014.

[54] T. Payum, "Distribution, ethnobotany, pharmacognosy and phytoconstituents of Coptis teeta Wall.: a highly valued and threatened medicinal plant of eastern himalayas," Pharmacognosy Journal, vol. 9, no. 6s, pp. s28-s34, 2017.

[55] S. Sujatha, S. Anand, K. N. Sangeetha et al., "Biological evaluation of (3 $\beta$ )-STIGMAST-5-EN-3-OL as potent antidiabetic agent in regulating glucose transport using in vitro model," International Journal of Diabetes Mellitus, vol. 2, no. 2, pp. 101-109, 2010.

[56] J. Lan, Y. Zhao, F. Dong et al., "Meta-analysis of the effect and safety of berberine in the treatment of type 2 diabetes mellitus, hyperlipemia and hypertension," Journal of Ethnopharmacology, vol. 161, pp. 69-81, 2015.

[57] A. Salatino, M. L. F. Salatino, and G. Negri, "Traditional uses, chemistry and pharmacology of Croton species (euphorbiaceae)," Journal of the Brazilian Chemical Society, vol. 18, no. 1, pp. 11-33, 2007.

[58] L. Liu, H. Yu, H. Wu et al., "Toxic proteins from Croton tiglium L. exert a proinflammatory effect by inducing release of proinflammatory cytokines and activating the p38-MAPK signaling pathway," Molecular Medicine Reports, vol. 16, no. 1, pp. 631-638, 2017.
[59] W. H. Xu, W. Y. Liu, and Q. Liang, "Chemical constituents from Croton species and their biological activities," Molecules, vol. 23, 2018.

[60] R. Chakraborty and V. Mandal, "In vitro hypoglycemic and antioxidant activities of Litsea cubeba (lour.) pers. Fruits, traditionally used to cure diabetes in darjeeling hills (India)," Pharmacognosy Journal, vol. 10, no. 6s, pp. s119-s128, 2018.

[61] M. Luo, L.-K. Jiang, and G.-L. Zou, "Acute and genetic toxicity of essential oil extracted from Litsea cubeba (lour.) pers," Journal of Food Protection, vol. 68, no. 3, pp. 581-588, 2005.

[62] R. Chakrabarti, B. A. Singh, P. Vn, L. T. Vanchhawng, and K. Thirumurugan, "Screening of nine herbal plants for in vitro $\alpha$-amylase inhibition," Asian Journal of Pharmaceutical and Clinical Research, vol. 7, 2014.

[63] A. B. Jaykumar, M. S. Shihabudeen, and K. Thirumurugan, "Screening of fifteen Indian ayurvedic plants for alphaglucosidase inhibitory activity and enzyme kinetics," International Journal of Pharmacy and Pharmaceutical Sciences, vol. 3, pp. 267-274, 2011.

[64] B. Vyas and A. C. Rana, "Phytopharmacological evaluation of hydro-alcoholic extract of Mesua ferrea stamen for their antioxidant and antidiabetic activity," Journal of Chemical and Pharmaceutical Research, vol. 5, pp. 341-349, 2013.

[65] U. Balekari, C. Veeresham, and C. Veeresham, "Insulinotropic activity of methanolic extract of Mesua ferrea Linn," Journal of Basic \& Applied Sciences, vol. 11, pp. 410-417, 2015.

[66] M. Asif, S. F. Jafari, Z. Iqbal et al., "Ethnobotanical and Phytopharmacological attributes of Mesua ferrea: a mini review," Journal of Applied Pharmaceutical Science, vol. 7, pp. 242-251, 2017.

[67] C. Rouger, S. Derbré, and P. Richomme, "Mesua sp.: chemical aspects and pharmacological relevance of prenylated polyphenols," Phytochemistry Reviews, vol. 18, no. 1, pp. 317-342, 2018. 